\title{
A Case of Foreign Body Laryngeal Granuloma Mimicking Contact Granuloma
}

\author{
Hye soo Kim ${ }^{\mathbb{D}}$, Sun woo Kim ${ }^{\mathbb{D}}$, Jin Lee $\mathbb{D}^{\mathrm{D}}$, and Sang Hyuk Lee $\mathbb{D}^{\mathbb{D}}$ \\ Department of Otorhinolaryngology-Head and Neck Surgery, Kangbuk Samsung Hospital, Sungkyunkwan University School of Medicine, \\ Seoul, Korea
}

접촉성 육아종으로 오인된 후두 이물 육아종 1예

김혜수, 김선우, 이 진, 이상혁

성균관대학교 의과대학 강북삼성병원 이비인후과학교실

Among lesions in the larynx, laryngeal contact granuloma due to persistent tissue irritation can typically be attributed to endotracheal intubation, vocal abuse, or gastro-esophageal reflux disease. Treatment typically includes voice therapy, lifestyle changes and use of anti-reflux medication. Microsurgical removal is only indicated in cases of severe dyspnea due to mass size. Foreign body granuloma is a response of to any foreign material in the tissue. Foreign body granulomas are sometimes misdiagnosed as soft tissue tumors when the causative foreign body is not initially found. Delayed treatment of these foreign bodies may cause complications. We present a case of larynx granuloma due to impacted foreign body, probably fish bone, in the larynx that mimicked contact granuloma. We initially used anti-reflux medication, but to no avail. The laryngeal mass, observed through laryngoscopy, showed no improvement and therefore necessitated a proper pathologic diagnosis. We were able to successfully treat it via trans-oral laser CO2 microsurgery before any complications developed.

Keywords Contact granuloma; Foreign body granuloma; Larynx; Foreign body; Treatment.

\section{서 론}

후두 병변 중에서 접촉성 육아종은 비교적 드문 질환으로, 다양한 원인으로 발생하는 것으로 알려져 있다. 병리기전은 명확히 밝혀지지 않았으나 몇몇의 유발요인이 알려져 있다. 기관 내 삽관, 음성 남용, 위식도 역류 질환, 정신신체화 질환 등이 그 요인이다. 다른 요인으로는 코나 부비동의 만성 염증과 인후두의 감염, 흡연도 그 원인이 될 수 있 다..$^{-3)}$ 증상은 가벼운 음성변화에서 심한 음성변화 혹은, 연하곤란, 객혈, 만성 기침 등 이 나타날 수 있다. 후두 미세 수술을 통한 병변 제거의 적응증은 병변 크기가 커서 호 흡곤란을 유발하는 경우나 조직학적 진단이 요구되는 경우 주로 시행하게 되는데, 이는 접촉성 육아종의 원인이 주로 개인 생활방식에 기인하므로 생활 방식 교정, 예로 음성 안정이나 위식도역류 질환의 치료 등이 선행되기 때문이다.2,3)

\author{
Received October 9, 2019 \\ Revised October 24, 2019 \\ Accepted November 12, 2019
}

\section{Corresponding Author}

Sang Hyuk Lee, MD

Department of Otorhinolaryngology-

Head and Neck Surgery,

Kangbuk Samsung Hospital,

Sungkyunkwan University

School of Medicine,

29 Saemunan-ro, Jongno-gu,

Seoul 03181, Korea

Tel +82-2-2001-2269

$\mathrm{Fax}+82-2-2001-2273$

E-mail entlsh@hanmail.net

\section{ORCID iDs}

Hye soo Kim (D)

https://orcid.org/0000-0001-9755-7419

Sun woo Kim (D)

https://orcid.org/0000-0002-2894-1334 Jin Lee (1)

https://orcid.org/0000-0003-2264-8310

Sang Hyuk Lee (1)

https://orcid.org/0000-0003-4412-3486

This is an Open Access article distributed under the terms of the Creative Commons Attribution Non-Commercial License (https://creativecommons.org/ licenses/by-nc/4.0) which permits unrestricted non-commercial use, distribution, and reproduction in any medium, provided the original work is properly cited. 
이물 육아종은 조직 내 이물에 대한 생물학적인 조직의 반 응이다. 쇠나 유리와 같은 비활성 이물의 경우 대개 특정 염 증을 일으키지 않을 수 있으나, 나무 조각이나 생선뼈와 같은 유기 이물질의 경우 2차적인 세균 감염 및 육아종을 일으킬 수 있으므로 반드시 제거해야 한다. 이러한 이물은 자체로 염증이나 면역반응을 일으킬 수 없는 물질이지만, 이물의 화 학적 특성이 육아종의 생성에 있어 기간과 정도 및 용해율을 다양하게 만든다.45) 이물은 조직 안에 둘러싸이게 되며 이 이물은 조직의 치유 반응을 변화시킨다. 이러한 조직의 이물 반응은 단백 흡수, 대식세포의 출현 및 대식세포의 융합체인 다핵 이물 거대세포, 섬유 아세포, 혈관 신생 등이 있다.5,6) 이 물 육아종은 이물이 보이지 않거나 확인되지 않게 되면, 연조 직 종양 등의 병변으로 오인될 수 있다.

저자들은 후두에 발생한 접촉성 육아종으로 진단되어 양 자 펌프 억제제(proton pump inhibitor) 치료 후 조직학적 검 사로 생선가시로 인한 후두 이물 육아종으로 최종 밝혀진 사 례를 문헌 고찰과 함께 보고하는 바이다.

\section{증 례}

42세 남자 환자가 1 달전부터 발생한 목안의 이물감을 주 소로 본원 이비인후과에 내원하였다. 이물감 외 인후통, 연하 곤란, 음성변화 등의 증상은 없었다. 흡연력은 없었으며 체중 $95.5 \mathrm{~kg}$, 신장 $168.1 \mathrm{~cm}$ 의 body mass index 33.8의 고도비만 환자였다. 환자의 과거력 및 가족력에는 특이 사항이 없었고, 특별히 기억되는 이물 섭취의 병력 또한 없었다. 이학적 검사 에서 경부 촉진 시 통증은 없었으며 만져지는 종괴도 없었다.

후두 내시경 검사에서 좌측 피열 연골 부에 접촉성 육아 종으로 의심되는 종물, 피열연골 사이 점막의 발적과 경미한 비후 그리고 성문하부종으로 인한 위성대구증(pseudosulcus vocalis) 소견이 관찰되었다(Fig. 1A). 이에 인후두 역류질환 의심하에 치료를 위하여 식습관 및 생활 습관 교정과 양자 펌프 억제제를 투여하여 10 개월 동안 경과관찰하며 추적하
였고 증상과 병변은 호전되었다.

약 30 개월 후 환자는 다시 2 개월전 발생한 목안 이물감 주 소로 본원에 내원하였다. 30 개월간 체중의 변화와 인후두 역 류 증상 호소는 없었다. 이전 좌측 피열 연골부의 접촉성 육 아종 소견은 관찰되지 않았으나, 우측 피열 연골에 다소 불규 칙한 표면을 가진 육아종성 병변으로 의심되는 종물이 관찰 되었다(Fig. 1B). 이에 인후두 역류로 인한 접촉성 육아종의 재발을 의심하여 식습관 및 생활 습관 교정과 양자 펌프 억제 제의 투여를 다시 시작하였다. 3 개월 후 재평가한 후두내시경 검사 상 종물의 크기는 약간 감소된 듯 보였으나, 발적과 거친 표면이 관찰되었고(Fig. 1C) 조직학적 검사가 필요할 것으로 판단되어 현수후두경하 후두 미세수술을 계획하였다.

후두 미세수술은 일반적인 방법으로 진행되었고, 환자의 구강에서 후두 내로 현수 후두경의 진입 시 특별한 어려움은 수반되지 않았다. 현수 후두경은 진성대까지 진전되었고, 우 측 피열 연골부의 육아종으로 추정되는 종물을 확인 한 후 $\mathrm{CO} 2$ laser를 이용하여 절제 및 지혈하였다. 지혈 후 현수 후 두경을 제거하였으며 수술 중 출혈량은 매우 적었다.

수술 후 우측 피열 연골부의 육아종성 병변에 대한 조직검 사 결과, 주변 육아조직에 둘러싸인 매우 작은 크기의 갈색에 서 검은색을 띤 이물이 발견되었다(Fig. 2A). 이물을 둘러싼 육아조직에는 호중구의 침윤과 재생되는 편평상피, 섬유성 괴사 조직이 동반된 만성 염증반응의 조직학적 소견이 관찰 되었다(Fig. 2B).

환자는 본원에서 수술 후 1 일째 퇴원하였다. 이후 수술 1년 후의 추적관찰에서 목안 이물감은 호전되었으며, 우측 피열 연골의 절제부는 재발 소견없이 조직이 잘 치유된 모습이 관 찰되었다(Fig. 3).

\section{고 찰}

후두의 육아종은 원형의 양성 병변으로 주로 성대 후부에 발생한다. 인후두 역류 질환, 음성 남용, 그리고 기관 내 삽관

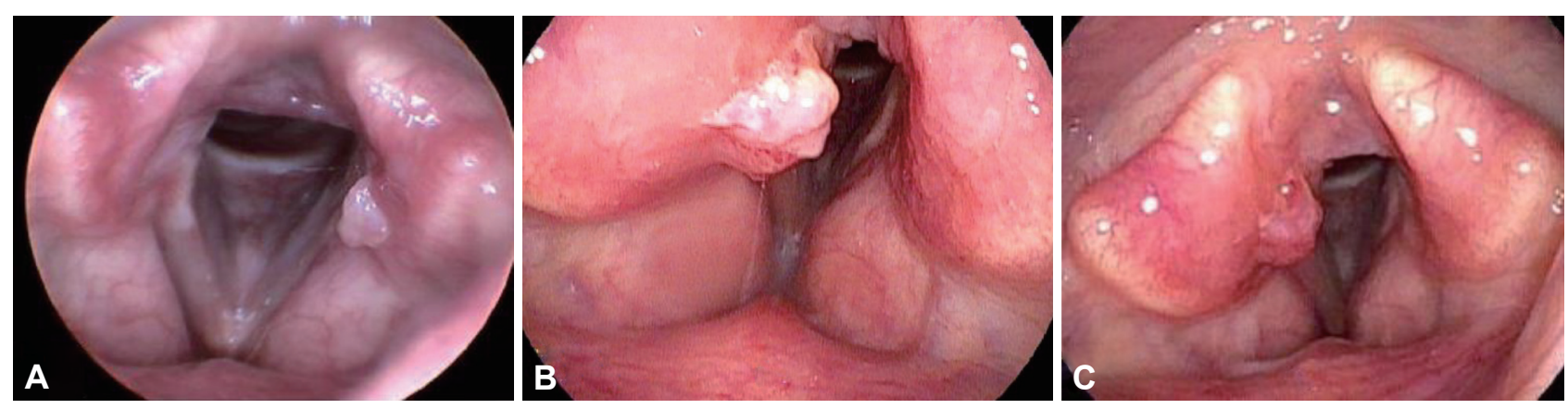

Fig. 1. Laryngoscopic findings. Granulomatous mass attached to the left arytenoid area (A), irregular surfaced Granulomatous mass on right arytenoid (B), more erythematous mass on right arytenoid after three months follow up (C). 

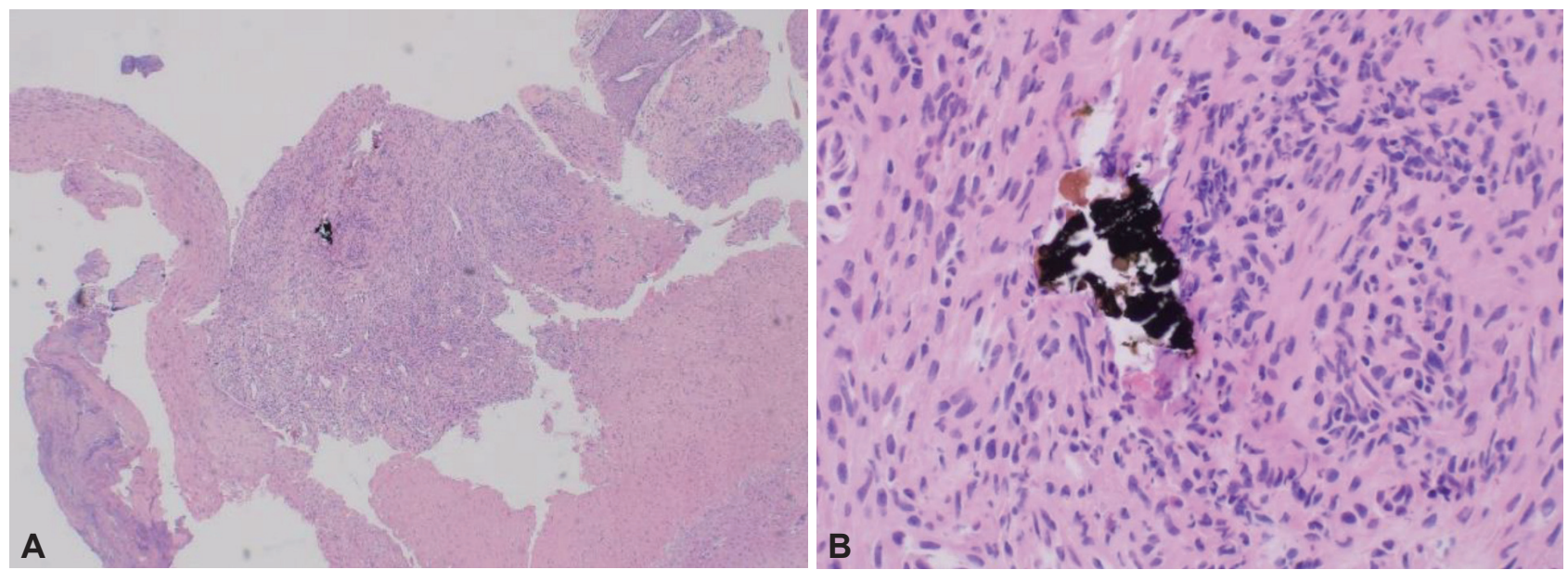

Fig. 2. Histologic finding. Tiny brownish and blackish foreign body was surrounded by the granulation tissue $(H \& E$ stain, $\times 1.25)(A)$, granulation tissue was composed of infiltrated neutrophils, squamous cells and fibrous necrotic tissues (H\&E stain, $\times 40)(B)$.

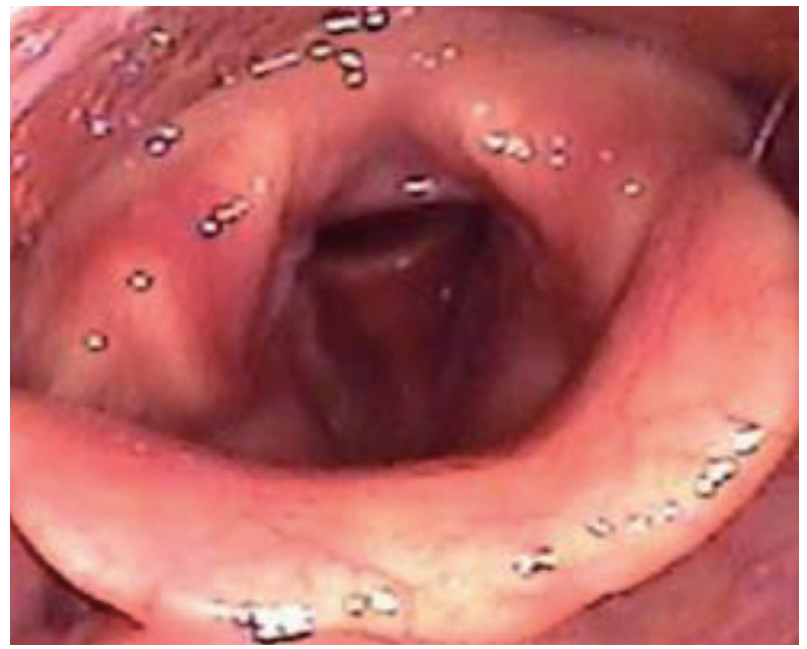

Fig. 3. Post operative laryngoscopic finding. One year after surgery. There was no recurrence and scar was healed without complication.

으로 인한 외상 등이 후두 육아종의 주요 원인이다. 다수에 서 양성 병변임에도 불구하고 재발률은 20 90\%에 이른다.) 후두 육아종의 원인이 다양하므로 표준 치료에 대한 일치된 합의는 없으나, 대개 보존적 치료를 먼저 시행하게 된다. 모든 경우에서 위식도 역류를 방지하는 식단에 대한 교육 또한 필 수적이다. 이러한 보존적 치료는 대개 치료 기간이 길다. 반면, 수술적 치료는 보존적 약물 치료가 실패한 경우 혹은 재발의 경우, 임상적으로 조직학적 진단이 필요하다고 판단되는 경우 가 그 적응증이 되며 치료 기간이 짧지만 전신 마취 및 입원이 필요하며 마취 및 수술로 인한 합병증에서 자유롭지 못하다. 그럼에도 기관 내 삽관으로 인한 후두 육아종 및 특발성 육 아종에서 수술적 치료는 보존적 치료보다 효과적인 것으로 알려져 있다. ${ }^{2,3)}$

본 증례의 환자는 후두의 이물 육아종으로 확진된 사례로
이물 섭취의 병력과 상기도의 폐색 증상 없이 목안의 이물감 만 호소하였다. 대부분의 후두의 이물의 경우, 소아 혹은 기 도 내 기침 반사가 저하된 성인의 경우에 일어나며 초기에 연 하곤란, 호흡곤란, 기침, 천명음, 협착음과 같은 급성 호흡기 폐색 증상을 나타낸다. 따라서 상기 증상 호소가 없었던 성 인의 본 증례의 경우는 후두부의 육아종의 원인을 규명하는 데 다소 어려움이 있었다. 몇몇 이물은 이처럼 급성 폐색 증 상을 유발하지 않으면서 오랜 기간 제거되지 않은 상태로 만 성적인 증상을 나타낼 수 있다.-10) 이물이 오랜 기간 제거되 지 않고 있는 경우 이물의 주변 조직에 염증반응 때문에 추 후 이물을 확인하기가 더 어려워지기도 한다. 또한 연조직의 종양 등의 병변으로 오인될 가능성도 있다. 이와 같은 이물 육아종의 확진은 조직검사를 통해서만 가능하다. 몇몇 증례 에서 덜 침습적인 세침 흡인 검사를 진단 도구로 언급하였으 나, 이 경우에도 조직학적 검사가 함께 시행되었다. ${ }^{45}$

이물 육아종은 다른 염증반응과 마찬가지로 역동적인 과 정으로 일어나게 된다. 초기 염증반응 시기에 이물을 둘러싼 호중구의 침윤이 대표적이며 대개 이러한 과정은 이물을 제 거하지 못하게 되고 후에 조직구와 이물을 섭취한 대식세포 의 출현으로 대체된다. 대식세포의 이물 섭취로 이물제거가 되는 경우도 있으나, 대개는 이물이 분해되어 대식세포의 세 포질에 남게 되고 이 대식세포가 서로 다른 사이토카인을 분 비하면서 다른 염증 세포들을 유인하게 된다. 각각의 대식세 포는 융합하여 다핵화된 이물 거대 세포를 이루며 림프구와 섬유 아세포가 출현하게 된다. 이러한 일련의 과정으로 이물 주위 육아종이 형성된다.6,11)

후두 육아종의 치료는 인후두 역류에 대한 식습관 개선과 양자 펌프 억제제가 보편적으로 시행되고 있으며 음성치료나 성대근 내 보톡스 주입술이 효과적인 것으로 알려져 있다. 수 
술적 제거는 단독으로 시행 시 재발의 가능성이 높아 다른 보 존적 치료보다 유의한 장점을 가지지는 못한다. ${ }^{1,12,13)}$ 그러나 보존적 치료에 반응을 보이지 않는 난치성 육아종에서는 본 사례처럼 인지되지 않은 이물로 인한 이물 육아종의 가능성 도 고려하여 후두 미세 수술을 통한 조직학적 진단 및 치료가 필요 할 수 있음을 염두해 두어야 하겠다. ${ }^{14,15)}$

중심 단어: 접촉성 육아종, 이물 육아종, 후두, 이물, 치료.

\section{Acknowledgments}

None.

Conflicts of Interest

The authors have no financial conflicts of interest.

\section{Authors' Contribution}

Conceptualization: Sang Hyuk Lee. Data curation: Hye soo Kim. Formal analysis: Hye soo Kim, Sun woo Kim, Jin Lee. Investigation: Hye soo Kim, Sang Hyuk Lee. Methodology: Hye soo Kim, Sang Hyuk Lee. Project administration: Hye soo Kim, Sun woo Kim, Jin Lee. Resources: Sun woo Kim, Jin Lee, Sang Hyuk Lee. Software: Hye soo Kim. Supervision: Sang Hyuk Lee. Validation: Sang Hyuk Lee. Visualization: Hye soo Kim, Sang Hyuk Lee. Writing-original draft: Hye soo Kim, Sang Hyuk Lee. Writing-review \& editing: Hye soo Kim, Sang Hyuk Lee. Approval of final manuscript: all authors.

\section{REFERENCES}

1. Lee SW, Hong HJ, Choi SH, Sun DI, Park YH, Lee BJ, et al. Comparison of treatment modalities for contact granuloma: a nationwide multicenter study. Laryngoscope 2014;124(5):1187-91.

2. Martins RHG, Dias NH, Soares CSP, Gramuglia ACJ. Treatment of Laryngeal Granulomas. Int Arch Otorhinolaryngol 2019;23(3): e322-4.

3. de Lima Pontes PA, De Biase NG, Gadelha EC. Clinical evolution of laryngeal granulomas: treatment and prognosis. Laryngoscope 1999; 109(2 Pt 1):289-94.

4. Mariano M. The experimental granuloma. A hypothesis to explain the persistence of the lesion. Rev Inst Med Trop Sao Paulo 1995;37(2): 161-76.

5. Joyce S, Rao Sripathi BH, Mampilly MO, Firdoose Nyer CS. Foreign body granuloma. J Maxillofac Oral Surg 2014;13(3):351-4.

6. Molina-Ruiz AM, Requena L. Foreign body granulomas. Dermatol Clin 2015;33(3):497-523.

7. Ylitalo R, Lindestad PA. Laryngeal findings in patients with contact granuloma: a long-term follow-up study. Acta Otolaryngol 2000; 120(5):655-9.

8. Sung CM, Yang HC, Jin SM, Jang CH. A missed and delayed detected fish bone impaction in subglottis. Korean J Otorhinolaryngol-Head Neck Surg 2019;62(1):57-9.

9. Gan BC, Abd Mutalib NS, Mamat H, Rahman HA. Impacted fish bone in the larynx masquerading as laryngeal papillomatosis: report of a rare case. Egypt J Ear Nose Throat Allied Sci 2016;17(3):163-5.

10. Chouhan M, Yadav JS, Bakshi J. Unusual presentation of foreign body in larynx. Egypt J Ear Nose Throat Allied Sci 2012;13(1):61-3.

11. Weedon D. The granulomatous reaction pattern. Weedon's skin pathology. China: Beijing, Elsevier; 2010. p.170-96.

12. Orloff LA, Goldman SN. Vocal fold granuloma: successful treatment with botulinum toxin. Otolaryngol Head Neck Surg 1999;121(4): 410-3.

13. Roh HJ, Goh EK, Chon KM, Wang SG. Topical inhalant steroid (budesonide, Pulmicort nasal) therapy in intubation granuloma. J Laryngol Otol 1999;113(5):427-32.

14. Kobayashi R, Tsunoda K, Ueha R, Fujimaki Y, Nito T, Yamasoba T. Role of lifestyle modifications for patients with laryngeal granuloma caused by gastro-esophageal reflux: comparison between conservative treatment and the surgical approach. Acta Otolaryngol 2017; 137(3):306-9.

15. Horiguchi S, Suzuki M, Takagi H, Yamanishi T, Nakamura K. Clinical course of laryngeal granuloma without surgical treatment. Diagn Ther Endosc 2001;7(3-4):129-33. 